\title{
Introduction to the Special Issue on Behavioural Finance
}

Citation for published version (APA):

de Bondt, W. F. M., Palm, F. C., \& Wolff, C. C. P. (2004). Introduction to the Special Issue on Behavioural Finance. Journal of Empirical Finance, 2004(11), 423-427. https://doi.org/10.1016/j.jempfin.2004.05.001

Document status and date:

Published: 01/01/2004

DOI:

10.1016/j.jempfin.2004.05.001

Document Version:

Publisher's PDF, also known as Version of record

\section{Please check the document version of this publication:}

- A submitted manuscript is the version of the article upon submission and before peer-review. There can be important differences between the submitted version and the official published version of record.

People interested in the research are advised to contact the author for the final version of the publication, or visit the DOI to the publisher's website.

- The final author version and the galley proof are versions of the publication after peer review.

- The final published version features the final layout of the paper including the volume, issue and page numbers.

Link to publication

\footnotetext{
General rights rights.

- You may freely distribute the URL identifying the publication in the public portal. please follow below link for the End User Agreement:

www.umlib.nl/taverne-license

Take down policy

If you believe that this document breaches copyright please contact us at:

repository@maastrichtuniversity.nl

providing details and we will investigate your claim.
}

Copyright and moral rights for the publications made accessible in the public portal are retained by the authors and/or other copyright owners and it is a condition of accessing publications that users recognise and abide by the legal requirements associated with these

- Users may download and print one copy of any publication from the public portal for the purpose of private study or research.

- You may not further distribute the material or use it for any profit-making activity or commercial gain

If the publication is distributed under the terms of Article $25 \mathrm{fa}$ of the Dutch Copyright Act, indicated by the "Taverne" license above, 


\section{Editorial \\ Introduction to the special issue on behavioral finance}

Twenty years ago, theoretical and empirical research in finance proceeded as if the human factor in financial decision making did not matter very much. Many financial economists admitted that the intuitive judgment of investors and their advisors revealed some shortcomings, but they also maintained that the forces of rational arbitrage ensured that market prices were efficient, i.e., stock prices quickly and adequately reflected all available information. The psychology of money was seen as a captivating topic (surely, for psychologists) but one that may well be "too interesting" for economists and that may distract them "from the pervasive market forces that should be [their] principal concern" (Miller, 1986, p. 283).

Today, this point of view is less widespread and it has become less plausible. One reason has to do with the extraordinary events of the 1980s and the 1990s (consider, e.g., the 1987 crash or the Nasdaq bubble). A second reason is that a new approach has emerged. Behavioral finance thinks about financial issues with the help of ideas borrowed from psychology. It not only casts doubt on the predictions of modern finance, such as the notion of efficient markets, but also on its micro-foundations, i.e., expected utility maximization, rational expectations and Bayesian updating. Prospect theory, mental frames, heuristics and related psychological concepts form the basis for a new theory of finance. Opinions differ, but so far, it appears, behavioral finance has been a fertile paradigm. In the area of asset pricing, for instance, it has been used to interpret and/or to discover empirical anomalies in the speculative dynamics of stock returns, e.g., under- and overreaction to news. Additionally, through detailed surveys and archival studies of trading behavior, a great deal has been learned about the conduct of investors, analysts, money managers and others. In corporate finance, the behavioral approach has stimulated interest in the determinants and the quality of executive decision making, e.g., excessive risk aversion, unjustified optimism, hubris and so on (Kahneman, 2002).

In October 2002, the Journal of Empirical Finance and the Limburg Institute for Financial Economics (LIFE) at the University of Maastricht jointly organized a conference on behavioral finance in Palma de Mallorca (Spain). Methodologically, behavioral finance operates at three levels: (i) it conducts experiments with subjects under controlled laboratory conditions; (ii) it studies real-world financial decisions made by individuals, households, financial professionals and corporations; and (iii) it looks into the behavior of financial markets. By design, all the papers presented at the conference dealt with topics in empirical asset pricing, i.e., either the behavior of investors (or their advisors) or the 
behavior of equity markets. Of specific interest was the controversial question of momentum in stock prices, asset classes, expert recommendations and related variables. We received approximately 50 paper submissions. Seven of the eight manuscripts published in this special issue of the Journal of Empirical Finance were discussed in Palma de Mallorca. We thank the authors, the discussants, the referees, as well as Ms. Yolanda Paulissen (the editorial assistant). In addition, we are grateful to Professor Louis Chan (University of Illinois at Urbana-Champaign) and Professor Meir Statman (University of Santa Clara) for presenting overview discussions of the contemporary literature on, respectively, momentum and the trading motives of individual investors.

The first four articles in the special issue look at different aspects of momentum strategies. Bange and Miller (2004) study the recommended global portfolio allocations among equity, bonds and cash and among six countries by a panel of investment houses between 1982 and 1999. (The quarterly recommendations are available to the public at minimal cost since they are published in The Economist.) Prior research has shown that investment newsletters advocate the purchase of securities that have performed well in the past (Jaffe and Mahoney, 1999) and that small individual investors buy and sell stocks as if past price movements may be extrapolated into the future (Bange, 2000). Interestingly, Bange and Miller find a similar pattern in the advice of the investment houses. The results are consistent with momentum trading. Then again, it may be that the investment houses see the advice first and foremost as a marketing opportunity.

Price momentum over 6-to 12-month horizons was observed in US data by, among others, Jegadeesh and Titman $(1993,2001) .{ }^{1}$ Later, Moskowitz and Grinblatt (1999) claimed that industry effects could account for much of the phenomenon. Nijman et al. (2004) ask whether equity price momentum in Europe has significant country and industry components. The short answer is no. Nijman et al. use monthly return data for 15 countries and 23 industries between 1990 and 2000. They introduce an innovative portfolio-based regression approach that has practical use to quantitative money managers. The chief substantive finding of Nijman et al. is that an investor who does not wish to take large country or industry bets may still be able to benefit from price momentum.

Chen and De Bondt (2004) suggest that investors can gain from equity style management. Their research is motivated in part by the pervasive use of the value/growth and small-cap/large-cap labels. Chen and De Bondt study all firms in the Standard and Poor's-500 index (1976-2000). Three characteristics (market value of equity, book-tomarket ratio and dividend yield) capture style-related trends in equity returns. Strategies that buy stocks with characteristics that are currently in favor (past winners) and that sell stocks with characteristics that are out of favor (past losers) perform well. Chen and De Bondt believe that style momentum is distinct from price and industry momentum. They offer evidence that the profitability of style momentum may be linked to changes in macro-economic and financial conditions. However, the fact that many investors trade

1 Analogous findings were reported by De Bondt and Thaler (1985, Table 1 and Fig. 2). However, De Bondt and Thaler did not emphasize momentum because they were more interested in 2- to 5-year price reversals which they attributed to investor overreaction. 
baskets of stocks - always chasing past winner styles and dumping losers - also seems a likely cause of style momentum.

The fourth and final paper on momentum is co-authored by Karolyi and Kho (2004). They devise a new test methodology - an estimation-based bootstrap simulation-to evaluate what fraction of price momentum profits may be explained by cross-sectional differences and time variation in expected returns, consistent with conventional asset pricing models and efficient markets. Karolyi and Kho consider a variety of returngenerating models (as well as different sampling techniques in the bootstrap simulations), but none of them is able to generate profits as large as the actual profits from a JegadeeshTitman price momentum strategy. Yet, selected models yield simulated profits that are a sizeable fraction of actual profits.

The next two papers in the special issue take up the well-known problem whether equity returns are predictable from their past history. This matter has been the focal point of a great deal of past research. Gropp (2004) uses a panel data approach to examine mean reversion in industry portfolios for the United States over the period 1926-1998. Some past tests that use traditional time-series methods have found litte evidence of mean reversion. However, Gropp's panel approach suggests that after temporary shocks, industry portfolios revert halfway toward their fundamental levels over $4-8$ years. These results, Gropp shows, can form the basis for a successful contrarian investment strategy.

Patro and $\mathrm{Wu}$ (2004) use variance ratio tests to examine the predictability of daily, weekly and monthly equity index returns for 18 industrialized countries over the period 1979-1998. Their contribution adds to the literature in several ways. For example, the paper evaluates prior work by French and Roll (1986), Chan et al. (2000) and others. It is found that over short horizons, equity indices in most (but certainly not all) countries show signs of return continuation and that a winner-loser momentum arbitrage strategy may be profitable. However, Patro and $\mathrm{Wu}$ emphasize that the findings must be interpreted with caution. For instance, some tests yield different results depending on whether the indices are expressed in local currency or in US dollars.

The final two papers of the special issue examine the specifically psychological mechanisms that influence the speculative dynamics of stock prices. In theory, there are three groups of (not mutually exclusive) behavioral causes for trends and reversals: (i) biased forecasts of future profit potential; (ii) biased forecasts of risk and/or risk attitudes that are in conflict with expected utility theory; and (iii) non-rational trading behavior that reflects (falsely imagined) technical patterns in prices, superstition, emotion, or fashion, and that is not linked to forecasts of business fundamentals in any way. The article by ElGalfy and Forbes (2004) belongs to the first category while the article by Hwang and Salmon (2004) belongs to the third.

Hwang and Salmon develop a new method to measure herding behavior by investors. They define herding as imitation and suppression (or absence) of private information. Hwang and Salmon investigate how the cross-sectional variation in factor sensitivities (e.g., in capital asset pricing model betas) evolves over time. The idea is to quantify deviations from equilibrium beliefs expressed in market prices. For instance, when investors herd around the market consensus, the cross-sectional variance of stock betas is expected to fall. Hwang and Salmon study the US and Korean stock markets between 1993 and 2002. They identify the Asian crisis and the Russian default as critical turning 
points in herding behavior. It is striking that herding goes down and that market efficiency improves during periods of market stress (see also Burstein, 1999).

The last paper, by El-Galfy and Forbes, reexamines the worthy question whether financial analyst forecasts of corporate profits are rational. Seasoned market observers (and, we should note, securities markets regulators) often hold false earnings expectations responsible for price bubbles. Over the years, numerous studies have documented excessive optimism ("hype") as well as other biases in analyst predictions. However, the prominent work of Keane and Runkle (1998) disputes these findings. El-Galfy and Forbes inspect the key assumptions in Keane and Runkle's modelling strategy, and they extend the research in multiple ways. The revised estimates for the United States (19831997) unmistakably show that analyst earnings forecasts are not rational with respect to publicly available information.

Finally, the editors of the special issue have the pleasure to announce that Mary M. Bange and Thomas W. Miller are the recipients of the Best Paper Award for their paper entitled "Return Momentum and Global Portfolio Allocations".

\section{References}

Bange, M.M., 2000. Do the portfolios of small investors reflect positive feedback trading? Journal of Financial and Quantitative Analysis 35, 239-254.

Bange, M.M., Miller, T.W., 2004. Return momentum and global portfolio allocations. Journal of Empirical Finance 11 (4), 429-459. (doi:10.1016/j.jempfin.2004.02.002)

Burstein, G., 1999. Macrotrading and Investment Strategies: Macroeconomic Arbitrage in Global Markets. Wiley, New York.

Chan, K., Hameed, A., Tong, W., 2000. Profitability of momentum strategies in international equity markets. Journal of Financial and Quantitative Analysis 35, 153-172.

Chen, H.-L., De Bondt, W.F.M., 2004. Style momentum within the S\&P-500 Index. Journal of Empirical Finance 11 (4), 483-507. (doi:10.1016/j.jempfin.2004.04.005)

De Bondt, W.F.M., Thaler, R.H., 1985. Does the stock market overreact? Journal of Finance 40, $793-808$.

El-Galfy, A.M., Forbes, W.P., 2004. Are forecasts of corporate profits rational? A note and further evidence. Journal of Empirical Finance 11 (4), 617-626. doi:10.1016/j.jempfin.2004.04.004

French, K.R., Roll, R., 1986. Stock return variances: the arrival of information and the reaction of traders. Journal of Financial Economics 17, 5-26.

Gropp, J., 2004. Mean reversion of industry stock returns in the U.S., 1926-1998. Journal of Empirical Finance 11 (4), 527-551. (doi:10.1016/j.jempfin.2004.04.002)

Hwang, S., Salmon, M., 2004. Market stress and herding. Journal of Empirical Finance 11 (4), $585-616$. (doi:10.1016/j.jempfin.2004.04.003)

Jaffe, J.F., Mahoney, J.M., 1999. The performance of investment newsletters. Journal of Financial Economics 53, $289-307$.

Jegadeesh, N., Titman, S., 1993. Returns to buying winners and selling losers: implications for stock market efficiency. Journal of Finance 48, 65-91.

Jegadeesh, N., Titman, S., 2001. Profitability of momentum strategies: an evaluation of alternative explanations. Journal of Finance 56, 699-720.

Kahneman, D., 2002. Nobel Lecture. Stockholm, Sweden.

Karolyi, G.A., Kho, B.-C., 2004. Momentum strategies: some boodstrap tests. Journal of Empirical Finance 11 (4), 509-536. (doi:10.1016/j.jempfin.2004.02.004)

Keane, M.P., Runkle, D.E., 1998. Are financial analysts' forecasts of corporate profits rational? Journal of Political Economy 106, 768-805.

Miller, M.H., 1986. Behavioral rationality in finance: the case of dividends. Journal of Business 59, $267-284$. 
Moskowitz, T., Grinblatt, M., 1999. Do industries explain momentum? Journal of Finance 54, 1249-1290.

Nijman, T., Swinkels, L., Verbeek, M., 2004. Do countries or industries explain momentum in Europe? Journal of Empirical Finance 11 (4), 461-481. (doi:10.1016/j.jempfin.2004.02.001)

Patro, D.K., Wu, Y., 2004. Predictability of short-horizon returns in international equity markets. Journal of Empirical Finance 11 (4), 553-584. (doi:10.1016/j.jempfin.2004.02.003)

Werner De Bondt*

Driehaus Center for Behavioral Finance, DePaul University, 1 E. Jackson Blvd. Chicago, IL 60604, USA E-mail address: wdebondt@depaul.edu Franz PalmChristian Wolff Maastricht University, Maastricht, The Netherlands

\footnotetext{
* Corresponding author. Tel.: +1-312-362-8394; fax: +1-312-362-6566
} 